DOI: 10.1515/ausp-2015-0032

\title{
Piso the Rambler: Travelling and Tracking in Cicero's Rhetoric Discourse
}

\author{
Levente PAP \\ Sapientia Hungarian University of Transylvania (Miercurea Ciuc, Romania) \\ Department of Humanities \\ paplevente@sapientia.siculorum.ro
}

\begin{abstract}
Travelling was not less popular in ancient times than nowadays. People would set out for distant lands with various purposes: to trade, to do business, to gain information, to further develop science, to fight a battle, to visit sacred sites, and last but not least, they travelled with political-administrative purposes. Those who returned from these voyages often shared their exotic experiences; sometimes they even put them down on paper (like Herodotus, Pausanias, Caesar, etc.). When somebody's journey or delegation had not been very successful, they could still cosmeticize the story when telling it in the City, in case there had not been any witnesses to tell otherwise. On the other hand, such cases could easily be exploited by the prosecutor in critical situations such as a trial: Cicero used this exact method in his attack against Piso.
\end{abstract}

Keywords: Cicero, travel, route, in Pisonem, discourse

Travelling is a motif which has not been studied the most thoroughly by classical philology. This is why a new tendency is in development which tries to compensate for this deficiency. The topic of this article is worth studying and fits well into the current trends of classical studies. Meijer's A History of Seafaring in the Classical World (2014) or Morley's Trade in Classical Antiquity (2007) are the best examples for this tendency.

Romans had a somewhat different attitude towards travelling than Greeks. They were much more earthbound than the latter nation, which is not so strange if we consider the fact that they had always been a continental nation. Being an agricultural community, at the beginning Romans would travel to distant lands only as part of some military operation, and even then, they did not feel like going back to those places, in spite of the rich souvenirs they brought back from their wanderings. When the pater familias made a trip to the market (where he would go most often) or when he was visiting his land in the country, he could not be gone for more than two nights. When any bad omen occurred prior to the departure, he immediately called off the journey (Ihm 2012 [1993]). 
Romans never really became sea people. They travelled by sea only out of obligation and necessity. They dreaded to be cut off from their beloved homeland or to die on sea, never to be buried properly and thus wander around restlessly in the afterlife. They may not have loathed exactly the sea, but at least they hated the naval powers. We may find evidence for this in Cicero's work entitled The Republic, where he talks about the thoughtfulness of Romulus to have chosen an ideal scene for founding the state (re publica). The proximity of the sea generally has a negative impact on a state because of the social, military and political dangers that come with it, and also because of the danger of moral decadence.

Romans were perfectly satisfied by withdrawing to their peaceful countryside mansions and listening to interesting stories about the exotic East, told by those who had been in those parts of the world. Not even pilgrimages to different sacred places had an important tradition within their culture - a very characteristic tradition for the Greeks and for the Eastern cultures, though. Romans were ready to participate only in very short-distance pilgrimages. One of their somewhat "bigger" pilgrimages was called the Feria Latina, when they ceremoniously marched out to the Mons Albanus. This festivity was always held in April. Its exact time was never fixed - the date of the festivity was always set and declared by the consul who had won the elections for the given year. The event was meant to celebrate the foundation of Rome (a commemoration of the bucolic Rome) and the reinforcement of the Latin fraternity, as well. All Latin cities (those of Latium) sent delegates to this festivity and they did not arrive with empty hands - they brought lambs, cheese and other products with them.

This negative attitude towards travelling can even be found in the example of the ancient Trojan Aeneas, and of Lucumo or Tarquinius, who had been fugitive wanderers, travelling only out of necessity, their only wish being to find a permanent home where they could settle down and make an end to their roaming. Therefore, it is not accidental that Roman priests were forbidden to travel. Nevertheless, the concept of travelling was not totally unknown for the Romans.

The officially delegated diplomats set out for professional journeys, craftsmen travelled to sell their goods or to share their experiences, artists (mostly actors) and intellectuals moved from place to place, eager to find a job or to learn new things. Cicero himself took part in such professional journeys - he went to Greece to study rhetoric and philosophy (cf. Inwood and Mansfeld 1997, Guite 1962, Scribne 1920) and, as a lawyer, he often did field-work at several crime scenes, looking for evidence. On one occasion he travelled to Sicily in order to shed light on the abuse of power exercised by propraetor Verres. He spent more than 50 days there doing research in the cold and rough weather (cf. Havas 1989).

Peasants would go to the nearby towns or sometimes a little further to sell their goods and to buy products they could not produce themselves. Merchants took great risks in order to gain big profit: they did not baulk at the idea of long 
travels on land or by sea. Rome was full of merchants as well, many of them coming from abroad. They gathered near the Ostia harbour to sell their goods. In the light of recent study results, the views on the commercial activities of the ancient world are quite different, and somewhat controversial. Those who have a positive view on ancient commerce presuppose that it was similar to the one in our days and see only a quantitative difference between the two (Rostovtzeff 1926, 10; 1957, 165-166; Hopkins 1978). The other camp, however, states that there is a quantitative and a qualitative difference as well between the commerce of the two different historical eras (Morley 2007).

Furthermore, official journeys often took place in the Roman Empire. Beginning with the third and second centuries, the diplomatic relationship between Rome and Greece became stronger; more and more rulers from the East came to visit Rome, while legates from Rome were sent to Greece or to the Eastern countries. At the same time, expeditions were made more and more often, e.g. between 136-133 Scipio Aemilianus travelled to Greece and to the East in order to explore the mentality and customs of the different peoples living there (Astin 1967). Explorations of distant lands were systematically organized by the Roman Empire: Maecenas himself travelled a lot between Rome and Greece (cf. Le Doze 2014). The emperor's leaving Rome was also a very important event - a fact corroborated by the coins having the inscription: Adventus Augusti. And, as the emperor was welcome in the provinces, he was just as much missed in Rome - the Fortuna Redux imprints are another numismatic evidence for this (cf. Dufraigne 1994).

Travelling by sea was especially detested by the Romans: Propertius says in his work that it is only the desire for profit that makes people so desperate as to set out on journeys across the sea and risk to die on waters (Eleg. III. 7. 1-18). He was not the only one with this negative attitude; the Romans' view on travelling by sea was somewhat similar to the way Europeans think about travelling by plane in our days: there are means of better convenience, but they are much slower, so people fall back upon the former. Cicero was not more of a sea-travelling fan either.

A sea voyage is a serious business, and in the month of July too. We got to Delos on the sixth day from Athens. On the 6th of July we got from the Piraeus to Zoster, with a troublesome wind, which kept us there on the 7th. On the 8th we got to Ceos with a pleasant voyage. Thence to Gyaros with a violent wind, though it wasn't against us. Hence to Syros, and from that to Delos; we in both cases accomplished the passage quicker than we could have wished. You have had experience of Rhodian open vessels: they are the worst things in the world for rough water. Accordingly, my intention is not to be at all in a hurry, nor to stir from Delos unless I see "Gyrae's headlands" all clear. (Cicero, ad Atticum, V, 12. [trans. Shuckburgh 1908]) 
Cicero tried to use this controversy around travelling in his verbal attack against Piso. Rhetoric was, for Cicero, a means to express political attitude just as much as anything else: according to him, the issues related to speech are strongly tied to different legal, moral and social values as well (Havas 1989). He formulated and announced his social and political responsibility in de inventione, and this theoretical presentation was also illustrated in his actions on several occasions. In his speech supporting Quintius he shed light on the Sulla-type proscriptions, the same way he did in a pro Roscio Amerino in the person of Chrysogonus. Then, in his speech against Verres, Cicero also represented the interests of the equestrian order by emphasizing - among other things - that, by excluding the knights from the courts, the aristocratic state ensured that the ransacking of governors - again, of aristocratic origins - could remain unpunished. For, even if their actions got reported, the ones judging them would be aristocrats as well, which means they would most probably exonerate them. This speech of Cicero does not lack political references either: as, beside the personal scores, it takes into consideration the fact that Piso and his associates exiled the one person who had taken pains to rebuild the politically instable state by revealing the Catilinarian conspiracy, and he interpreted his unfortunate situation as having become the poor victim of the unfolding dictatorship.

Lucius Calpurnius Piso was the consul in 58 BC. His activity on the political scenery can first be noticed in 59 BC. This was the time when the tribune P. Clodius accused him (and not without any ground) of having robbed, as a praetor, the provinces under his control. This year, however, also brought some real success to Piso: he managed to marry his daughter Calpurnia to one of the consuls of that year, Caius Iulius Caesar. This fortunate marriage paid off quite early: with the support of his new son-in-law he was elected consul of the year, together with Aulius Gabinius, supported by Pompeius. Thus, practically, all of the consuls were completely under the influence of the triumvirs. This new legislative body, consisting of Clodius, Piso and Gabinius, created several laws that were favourable to Caesar and his appropriates, e.g. leges Aeliae et Fufiae. They re-established the collegia, and limited the power of the censors who, from that time on, were not authorized to exclude anybody from the senatus. In January or February 58 BC Clodius submitted two draft laws, both of them being aimed against Cicero: the lex de exilio Ciceronis and the lex de capite civis Romani. The latter lays down that anyone who exiles or executes a Roman citizen without a given order of the senatus, shall be sent to exile themselves (interdicere aqua et igni). At first, Piso had a good relationship with Cicero, the consul in $63 \mathrm{BC}$, he even approved of Cicero's ardent actions against the Catilinarians. However, he also maintained a good relationship with the pro-Catalinarian Cethegus. Piso did not tolerate the execution of the Catalinarians, and what is more, he even supported, together with another consul, the tribune Clodius in sending Cicero in exile. 
After Cicero's exile, when the terms of his office ended, Piso became the governor of the Roman province of Macedonia. However, after plundering the province for two years, in $55 \mathrm{BC}$ the senatus appointed another governor instead of Piso, in the person of Quintus Ancharius.

After his return, Cicero could not wait to take revenge on Piso for his contribution in Cicero's exile. On Piso's revocation debate Cicero did not spare his enemy who, after his return from Macedonia, expressed his indignation about it. As a way of 'propitiation' Cicero addressed his enemy by a vituperation known as in Pisonem.

Taking into consideration the history of their relationship, Cicero loathed Piso and tried everything to succeed in his attack against him. His offence aimed at several areas of Piso's life, bringing up problems regarding his personal life, ridiculing his origins and his world-view. Beside all these means of pillory, he thought it important to show the judges Piso's travelling habits. As we have already mentioned before, after an unfortunate governing period in Macedonia, Piso got revoked from the province. His return, however, cannot be considered a successful one at all, since he could not come back triumphantly. In relation to Piso's disgraceful return Cicero does not forget to point out that he came back from Macedonia without any glorious deeds which could have earned him the right to a triumph, and that such a thing had rarely happened before in the case of this Roman province (this statement might be a little bit exaggerated). Piso's return raises suspicion even from the beginning, says Cicero: his departure took place in wintertime when sailing is quite dangerous due to the extreme weather conditions. As we have mentioned before, Cicero was not very fond of travelling by sea. One might imagine how wicked a man must be, or in how big a trouble he must be, if he does not have any other choice but to embark on a ship in wintertime. According to Cicero, such a decision can only be made by a rascal:

... and then, in order that there should be something which might be recorded and engraved on the pedestal of his trophies, when, on his departure from his province, he arrived at Dyrrachium, he was besieged by those very soldiers whom he told Torquatus just now, in answer to his questions, had been disbanded by him out of kindness. And when he had assured them with an oath that he would pay them the next day all that was due to them, he hid himself at home; and then on a very stormy night, in slippers and in the garb of a slave, he embarked on board a ship, and avoided Brundusium, and sailed towards the furthest part of the coast of the Adriatic Sea; while, in the meantime, the soldiers at Dyrrachium began to besiege the house in which they thought that he was, and as they thought that he was hiding himself there, they began to set fire to it. And the people of Dyrrachium, being alarmed at that proceeding, told them that their "Imperator" had fled away by night in his slippers. Then the troops displace, and throw down, 
and deface, and destroy a statue of his, an excellent likeness of him, which he had caused to be erected in the most frequented place, that the recollection of so delightful a man might not perish; and in this way they expended on his likeness and on his effigy the hatred which they had hoped to wreak on himself. (Pis. 92-93 [trans. Yonge 1891])

It is not enough that he departed in wintertime, but he also chose to embark in a small port instead of a big and busy one, which suggests that he is not an honourable man. It is the same situation as nowadays when criminals choose the smaller and less frequently visited airports, where they have a bigger chance to get away unnoticed, instead of big airports with higher security control. In other words, Piso had to escape like a criminal, for he had been governing the province so dishonestly that its citizens banished him.

After his arrival to Italy, he continued to travel shamefully on different quirky roads till he reached Rome. As we know quite well, honest people prefer the direct roads, as those are the safest ones and they offer the shortest way between two endpoints. On the other hand, guilty people such as Piso, need to take the risk and look for the more dangerous, less taken roads which offer them a hiding place. Then, so as to emphasize the lugubriosity of Piso's return, Cicero compares it with a triumphant return, that of his own:

But since we have begun to institute a comparison between our fortunes we will say no more of the return of Gabinius, whom, though he has cut the ground from under his own feet, I still wish to see to admire the impudence of the man. Let us, if you please, compare your return with mine. Mine was such that the whole way from Brundusium to Rome I was beholding one unbroken line of the inhabitants of all Italy. For there was no district nor municipal town, nor prefecture, nor colony, from which a deputation was not sent by the public authority to congratulate me. Why should I speak of my arrival in the different towns? why of the crowds of men who thronged out to meet me? why of the way in which the fathers of families with their wives and children gathered together to greet me? why of those days which were celebrated by every one on my arrival and return, as if they had been solemn festival days of the immortal gods?

That one day was to me like an immortality, on which I returned to my country, and saw the senate which had come forth to meet me, and the whole Roman people; while Rome itself, torn, if I may so say, from its foundations, seemed to come forward to embrace her saviour. Rome, which received me in such a manner that not only all men and all women of all classes, and ages, and orders of society, of every fortune and every rank, but that even the walls and houses of the city and temples appeared to be exulting. And on the 
succeeding days, the pontiffs, the consuls, the conscript fathers, placed me in that very house from which you had driven me, which you had pillaged, and which you had burnt and voted that my house was to be built up for me again at the public expense, an honour which they had never paid to any one before. Now you know the circumstances of my return. Now compare yours with it, since, having lost your army, you have brought nothing safe back with you except that pristine countenance and impudence of yours. And who is there who knows where you first came to with those laurelled lictors of yours? What meanders, what turnings and windings did you thread, while seeking for the most solitary possible places? What municipal town saw you? What friend invited you? What entertainer beheld you? Did you not make night take the place of day? solitude of society? a cookshop of the town? so that you did not appear to be returning from Macedonia as a noble commander, but to be being brought back as a disgraced corpse? and even Rome itself was polluted by your arrival.

[...] and in this manner he, the Macedonian "Imperator," returning home from his mighty and from his important province, after three years government, entered the city in such a guise that no obscure peddler ever returned home in a more solitary condition [...]. (Pis. 51-54. [trans. Yonge 1891])

Cicero also points out that after his arrival in the city, Piso was still looking for the least frequented city gate instead of the main gate. Piso tries in vain to reject this accusation by saying that, in fact, he entered the city through the porta Caelimontana, which is not an obscure entrance of the city, for Cicero is able to manage the awkward situations very artfully:

When I said that he had entered the city by the Caelimontane gate, that ever ready man wanted to lay me a wager that he had entered by the Esquiline gate; as if I was bound to know, or as if any one of you had heard, or as if it had anything on earth to do with the matter, by what gate you had entered, as long as it was not by the triumphal one; for that is the gate which had previously always been open for the Macedonian proconsuls. You are the first person ever discovered who, having been invested with consular authority there, did not triumph on your return from Macedonia.

(Pis. 55. [trans. Yonge 1891])

The motif of the journey and facts of travelling appear in numerous ways in European literature, but its application in such a witty way shows Cicero's excellent rhetoric skills and techniques. He employs the unfortunate story of Piso's journey to question the trustworthiness of his enemy and finally to defeat him. However, the use of such attacking means is not so frequent in Cicero's oeuvre. 


\section{Works cited}

Astin, A. E. 1967. Scipio Aemilianus. Oxford: OUP.

Berry, D. H., 2006. Cicero: Political Speeches. A New Translation. Oxford: OUP, XXIV-XXXIX.

Dufraigne, P. 1994. Adventus Augusti, Adventus Christi. Recherche sur l'exploitation idéologique et littéraire d'un cérémonial dans l'Antiquité tardive. [Adventus Augusti, Adventus Christi. Research on the Ideological and Literary Exploitation of a Ceremony in Late Antiquity.] Paris: EA Institut d'Études Augustiniennes.

Fedelli, Paolo. 2006. Sextus Propertius. Elegiarum libri IV. Berlin: De Gruyter.

Guite, Harold. 1962. Cicero's Attitude to the Greeks. Greece and Rome (Second Series), vol. 9. no. 2: 142-159.

Harland, Philip A., ed. 2011. Travel and Religion in Antiquity. (Studies in Christianity and Judaism, vol. 21.) Waterloo: Wilfrid Laurier University Press. Havas L., ed. 1989. De Signis. In C. Verrem actionis secundae liber IV. Budapest: Tankönyvkiadó.

Hopkins, K. 1978. Conquerors and Slaves. Cambridge: CUP.

Ihm, Maximilian, ed. 2012 [1993]. Gaius Suetonius Tranquillus, Opera. Vol. 1. Berlin: De Gruyter.

Inwood, B., and J. Mansfeld, eds. 1997. Assent and Argument: Studies in Cicero's Academic Books. Leiden: Brill.

Le Doze, Philippe. 2014. Mécène: ombres et flamboyances. [Patrons: Shadows and Flamboyances.] (Études anciennes. Série latine, 78.) Paris: Les Belles Lettres.

Meijer, Fik. 2014 [1986]. A History of Seafaring in the Classical World. New York: Routledge.

Morley, Neville. 2007. Trade in Classical Antiquity. Cambridge: CUP.

Rostovtzeff, Michael Ivanovitch. [1926]. The Social \& Economic History of the Roman Empire. New York: Biblo \& Tannen.

---. 1957. The Social \& Economic History of the Roman Empire. Oxford: Calderon. Shuckburgh, Evelyn. 1809, 1909. Cicero. The Letters of Cicero; the Whole Extant Correspondence in Chronological Order, in Four Volumes. London: George Bell and Sons.

Scribne, S. Henry. 1920. Cicero as a Hellenist. The Classical Journal vol. 16. no. 2: 81-92. Monmouth: The Classical Association of the Middle West and South.

Yonge, C. D., trans. 1891. M. Tullius Cicero. The Orations of Marcus Tullius Cicero. London: George Bell \& Sons.

Yonge, C. D., trans. 1877. Cicero on the Commonwealth. New York: Harper \& Brothers Publishers. 